\title{
The impact of cooperative learning and direct instruction on Saravan Islamic Azad university student's math progress in first half of educational year 2013-2014
}

\author{
Abdol Hamid Parsafar ${ }^{1 *}$, Azizollah Nosrat ${ }^{2}$ \\ ${ }^{1}$ Department of Educational Sciences, Saravan Branch Islamic Azad University, Saravan, Iran \\ ${ }^{2}$ Department of Applied Mathematics, Saravan Branch, Islamic Azad University, Saravan, Iran \\ *Corresponding author E-mail: parsafar@mail.iausaravan.ac.ir
}

\begin{abstract}
The aim of this study is to compare the impact of cooperative learning and direct instruction on Saravan Islamic Azad University student's math progress in first half of educational year 2013-2014. Research method is semi - trial of unequal control group with pre and post - test. Population of the sample includes all students of first half of 2013-2014 educational year that have taken math courses in Saravan Unit and the number of them is 130.65 subjects are in control group and 65 subjects are in test group. There were 35 female students and 30 male students in each group. Measurement tools in this study are researcher built math progress and Rion's Intelligence test. Subjects of the study first participated in pre - tests and then instructed by cooperative learning method for 10 weeks and after that post - tests were done and required data were collected. In order to analyze the data, t-test was used. Results showed that math progress of test group with cooperative method, was higher than the control group that were instructed by direct method and the difference was significant .in addition, it was con-cluded that there is no significant math progress in two females and males groups.
\end{abstract}

Keywords: Progress; Cooperative Learning; Direct Instruction; Math.

\section{Introduction}

One of important and controversial subjects in educational psychology area, is learning in human. What is learning and how does it happen? This is a common subject of many psychological schools but the basic difference among them is in terms of learning quality and the way human learns. Low efficiency of traditional teaching and learning methods, ever increasing of human knowledge, scientific advances as a result of technology development and hundreds of factors has led scholars and experts in education want to find new solutions and do investigations to make basic changes in learning and teaching methods and modify and improve educational systems performance. Cooperative learning and types of styles used in this method, beside improving learners' learning, have had other positive results such as better relationship between students group, academic achievement, more self - believe in students, creating motivation for participation in group activities and etc. in this method, students in groups learn together and if they achieve to a reasonable level of learning and achievement, to would obtain team awards and other certificates (Slavin, 2014).

The main objective of all educational systems is creating learning in students. The tool for providing learning is instruction and based on the definition, instruction is "activities that devise by the teacher for creating learning in learner and these activities flow between teacher and one or more learners in the form of mutual action or interaction, whether this teacher is teaching in elementary school or teaching in university (Saif, 2013).

Khoshbakht (2001) reported that application of cooperative method significantly has affected learning of the students. Talebi
(2003) also in an empirical study proved advantage of cooperative learning.

The question is that is it possible to use active methods such as cooperative learning instead of traditional and common learning methods? Thus, in this study we aim to compare the impact of cooperative learning and direct instruction on Saravan Islamic Azad University student's math progress to be able to use the results in order to modify and improve the current procedure of education and students learning strategies. Cooperative instruction method is a good alternative for common teaching methods specially presentations. Saif (2013) says that cooperative learning is supported by strong theories and precise empirical advocacies. Theoretically this method also is supported by behaviorists and other scholars in learning confirm it.

It's about 30 years that cooperative learning pattern is of certain attraction as an important and influential approach in educational systems. Experiences of these years has shown that when teachers put students in multi member groups and do instruction cooperatively, lead the students to more self-confidence thus they get better scores (Bahmaei, 2001). This approach is the result of thoughts of scholars who wanted to get knowledge of children's learning through experience. They were strongly against the idea that students should be passive and under teachers control and believed that experience has the most important role in learning process if it be companied by regular and rational analysis (Shabani, 2011).

Novel viewpoint of math teaching emphasizes on the fact that transferring math concepts and skills by teacher passively don't provide significant learning for learners and never leads to growth and dynamic math thought. These are the learners who make math into things understandable and enjoyable with active participation 
in teaching and learning math. Production, fixation, and enhancement of math thought for learners occur when they participate in making new math concepts and skills with their teacher's leading (Alamolhodaei,2009).

Slavin (2012) suggests that beside the fact that cooperative learning is one of important topics of research and theory, it is used widely by millions of teachers. Recent national investigation shows that $79 \%$ of elementary school teachers and $62 \%$ of high school teachers use this method in their classes.

Herried (2000) says that more than 1200 research done has proved the advantage of cooperative method over traditional methods such as competitive and individual.

\section{Methodology}

The population of the study includes all Islamic Azad University of Saravan who took math course in first half of 2013-2014 educational year that were about 400 students. In this study two classes for control group and two classes for Test group were chosen randomly which contained 130 students. Sampling method used in this study was random cluster sampling. In random cluster sampling, clusters are used instead of individuals as sampling unit Delavar (2013) says that in this sampling method measurement unit is not the person but a group of people that are formed naturally and has made their own group.

Finally 4 classes were chosen as sample which 2 classes (60 people) were boys and 2 classes (70 people) were girls.

In order to conduct research plan, data required for comparison of subjects' math progress in control and Test groups was obtained by math progress test. In fact this measurement tool is used in pre and post - test and necessary comparisons between these two learning methods are conducted by the results.

Rion's intelligence was used to equalize control and Test groups. Because in this research, scholars couldn't put subjects in study groups randomly so semi - experimental plan of unequal contro group was used. Unequal control group framework consists of two groups that were contrasted before and after exposure to independent variable. Figure below shows this scheme:

Test Group T2

Control group T2

In conducting this study, subjects of two groups were equalized in terms of intelligence variable using Rion's adult intelligence test and then math progress pre - test was performed in order to measure the impact of experimental variable. After that, about, 10 educational weeks independent variable was considered and finally math progress post - progress was conducted and groups were compared.

\section{Findings}

\subsection{Descriptive findings}

In this section, descriptive tables and diagrams resulted from research data in pre and post - tests and students' math progress post - test in cooperative and direct learning methods in two pre and post - tests are presented separately:
Table 1: Students' Scores Frequency Table in Cooperative and Direct Learning Pre - Test

\begin{tabular}{llll}
\hline Score & F & F.P & C.F.P \\
\hline 10.5 & 1 & 1.5 & 1.5 \\
11 & 2 & 3.1 & 4.6 \\
11.5 & 4 & 6.2 & 10.8 \\
12 & 3 & 4.6 & 15.4 \\
12.5 & 2 & 3.1 & 18.5 \\
13 & 9 & 13.8 & 32.3 \\
13.5 & 7 & 10.8 & 43.1 \\
14 & 12 & 18.5 & 61.5 \\
14.5 & 6 & 9.2 & 70.8 \\
15 & 7 & 10.8 & 81.5 \\
15.5 & 1 & 1.5 & 83.1 \\
16 & 4 & 6.2 & 89.2 \\
16.5 & 3 & 4.6 & 93.8 \\
17 & 3 & 4.6 & 98.5 \\
18 & 1 & 1.5 & 100 \\
total & 65 & 100 & \\
\hline
\end{tabular}

Table 2: Students' Scores Frequency Table in Cooperative and Direct Learning Post - Test

\begin{tabular}{llll}
\hline Score & F & F.P & C.F.P \\
\hline 11 & 2 & 3.1 & 3.1 \\
12 & 6 & 9.2 & 12.3 \\
12.5 & 6 & 9.2 & 21.5 \\
13 & 9 & 13.8 & 35.4 \\
13.5 & 7 & 10.8 & 46.2 \\
14 & 10 & 15.4 & 61.5 \\
14.5 & 7 & 10.8 & 72.3 \\
15 & 4 & 6.2 & 78.5 \\
15.5 & 4 & 6.2 & 84.6 \\
16 & 4 & 6.2 & 90.8 \\
16.5 & 3 & 4.6 & 95.4 \\
17.5 & 2 & 3.1 & 98.5 \\
18 & 1 & 1.5 & 100 \\
total & 65 & 100 & \\
\hline
\end{tabular}

Table 3: Descriptive Statistics of Raven's Intelligence Test in Two Control and Test Groups

\begin{tabular}{llllll}
\hline Test & Group & $\mathrm{N}$ & $\mathrm{M}$ & S.D & S.D.E \\
\hline intelligence & control & 65 & 101.3 & 1.65 & 0.412 \\
test & Test & 65 & 99.3 & 1.56 & 0.398 \\
\hline
\end{tabular}

In order to examine normality of data, Kolmogorov-Smirnov test was used which the results are in in following tables.

Table 4: Table of Subjects' Normal Distribution in Post - Test

\begin{tabular}{ll} 
Paraeters & \\
\hline $\mathrm{N}$ & 65 \\
Mean & 13.2701 \\
Std.Deviation & 1.2516 \\
Absolute & 0.111 \\
Most Extreme positive & 0.099 \\
Differences Negative & -0.111 \\
Kolmogorov-Smirnov Z & 1.115 \\
Asymp.Sign.(2-tailed) & 0.091 \\
\hline
\end{tabular}

Based on the data in the table above about study was normal. Because data from academic progress post - test score was $1.115 \mathrm{Z}$ and significant level of that also was 0.091 (more than 0.05) thus we can conclude that post test scores of sample group have normal manner. 


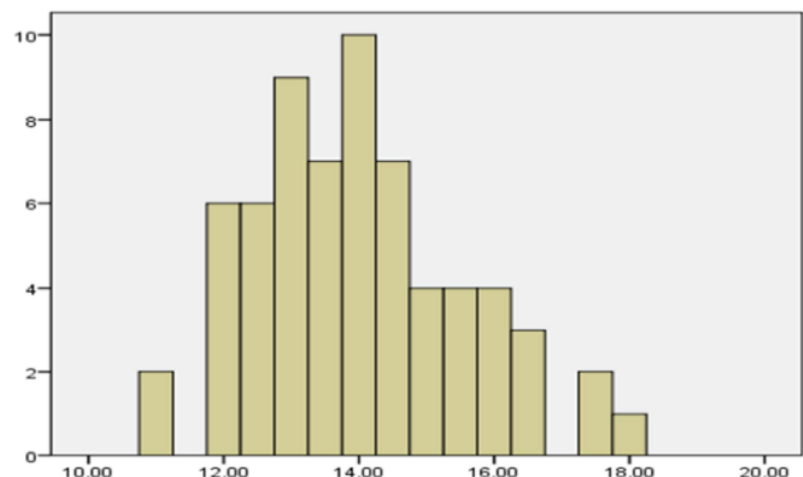

Fig. 1: Normal Distribution of Subjects in Post - Test.

Table 5: Descriptive Statistics of Subjects' Scores in Academic Progress Pre and Post - Test

\begin{tabular}{|c|c|c|c|c|c|c|c|c|}
\hline \multirow{2}{*}{$\begin{array}{l}\text { Index } \\
\text { group }\end{array}$} & \multicolumn{2}{|l|}{ M } & \multicolumn{2}{|c|}{ S.D } & \multicolumn{2}{|l|}{$\mathrm{V}$} & \multicolumn{2}{|l|}{ S.D.E } \\
\hline & $\begin{array}{l}\text { Pre } \\
\text { test }\end{array}$ & $\begin{array}{l}\text { Post } \\
\text { test }\end{array}$ & $\begin{array}{l}\text { Pre } \\
\text { test }\end{array}$ & $\begin{array}{l}\text { Post } \\
\text { test }\end{array}$ & $\begin{array}{l}\text { Pre } \\
\text { test }\end{array}$ & $\begin{array}{l}\text { Post } \\
\text { test }\end{array}$ & $\begin{array}{l}\text { Pre } \\
\text { test }\end{array}$ & $\begin{array}{l}\text { Post } \\
\text { test }\end{array}$ \\
\hline Test & 13.66 & 15.75 & 1.49 & 1.53 & 1.42 & 1.50 & 0.198 & 0.21 \\
\hline Control & 14.00 & 13.99 & 1.56 & 1.65 & 1.56 & 1.75 & 0.195 & 0.205 \\
\hline
\end{tabular}

Based on the data and statistics presented in tables, we can conclude that average score of subjects scores of two control and Test groups in pre - test and post - test were different and this difference for subjects of two groups in pre - test is nearly the same level and is significant for post - test.

Comparison of learning variables doesn't have the same level and average difference of them in pre - test is not significant in terms of statistics but is significant in post - test. From the information of the following table we can understand that average score of Test group which are instructed by cooperative method, has what order.

Table 6: Descriptive Statistics of Test Group Scores in Post - Test

\begin{tabular}{llllll}
\hline Index & M & S.D & V & S.E & Curvature \\
\hline & 15.75 & 1.53 & 1.50 & 0.21 & -0.430 \\
\hline
\end{tabular}

And also data of the following table shows statistics of control group which are examined traditionally and typically.

Table 7: Control Group Scores' Descriptive Statistics in Post - Test

\begin{tabular}{llllll}
\hline Index & $\mathrm{M}$ & S.D & V & S.E & Curvature \\
\hline & 13.99 & 1.65 & 1.75 & 0.205 & -0.414 \\
\hline
\end{tabular}

Data of the next table shows separated statistics relative to gender's statistics population.

Table 8: Separated Statistics Relative to Population's Gender

\begin{tabular}{llllll}
\hline $\begin{array}{c}\text { Index } \\
\text { gender }\end{array}$ & $\mathrm{M}$ & $\mathrm{S} . \mathrm{D}$ & $\mathrm{V}$ & $\mathrm{S} . \mathrm{E}$ & Curvature \\
\hline girl & 14.02 & 1.63 & 0.904 & 0.42 & 0.52 \\
Boy & 13.95 & 1.703 & 0.846 & 0.38 & -1.7 \\
\hline
\end{tabular}

\subsection{Hypothesis test}

In this section, findings of the study are analyzed by SPSS software. Because this study has two independent sample of the same population, significant t-test was used to test the hypotheses. First, the results of independent t-test are presented for investigation of significant intelligence scores in two control and Test groups.

Table 9: T-Test Results for Investigation of Significant Average of Intelligence Scores in Two Groups

\begin{tabular}{|c|c|c|c|c|c|c|c|c|}
\hline $\begin{array}{l}\text { Index } \\
\text { Group }\end{array}$ & $\mathrm{N}$ & M & $\begin{array}{l}\text { M.S. } \\
\text { E }\end{array}$ & $\begin{array}{l}\text { M.D.S. } \\
\text { E }\end{array}$ & $\begin{array}{l}\text { S.E.D. } \\
\text { M }\end{array}$ & $\begin{array}{l}\text { F. } \\
\text { D }\end{array}$ & $\mathrm{T}$ & S.G \\
\hline Test & $\begin{array}{l}6 \\
5\end{array}$ & 14.7 & 1.83 & 0.412 & \multirow[b]{2}{*}{0.414} & \multirow{2}{*}{$\begin{array}{l}12 \\
8\end{array}$} & \multirow{2}{*}{$\begin{array}{l}0.12 \\
0\end{array}$} & \multirow{2}{*}{$\begin{array}{l}0.89 \\
5\end{array}$} \\
\hline $\begin{array}{l}\text { Con- } \\
\text { trol }\end{array}$ & $\begin{array}{l}5 \\
6 \\
5\end{array}$ & $\begin{array}{l}14.0 \\
0\end{array}$ & 160 & 0.398 & & & & \\
\hline
\end{tabular}

Based on the data in table above, it is possible to infer that Test and control groups are the same in terms of intelligence control variable. It means that there is no significant difference in terms of intelligence degree at $\mathrm{P}<0.05$ level.

Table 10: Table Related to Math Progress Pre - Test of Subject Groups

\begin{tabular}{|c|c|c|c|c|c|c|c|c|}
\hline $\begin{array}{l}\text { Index } \\
\text { Group }\end{array}$ & $\mathrm{N}$ & M & $\begin{array}{l}\text { M.S. } \\
\text { E }\end{array}$ & $\begin{array}{l}\text { M.D.S. } \\
\text { E }\end{array}$ & $\begin{array}{l}\text { S.E.D. } \\
\text { M }\end{array}$ & $\begin{array}{l}\text { F. } \\
\text { D }\end{array}$ & $\mathrm{T}$ & S.G \\
\hline Test & 6 & 13.6 & 1.49 & 198 & \multirow{3}{*}{0.185} & \multirow{3}{*}{$\begin{array}{l}12 \\
8\end{array}$} & \multirow{3}{*}{$\begin{array}{l}1.12 \\
6\end{array}$} & \multirow{3}{*}{$\begin{array}{l}0.21 \\
6\end{array}$} \\
\hline & 5 & 6 & & 0.190 & & & & \\
\hline $\begin{array}{l}\text { Con- } \\
\text { trol }\end{array}$ & $\begin{array}{l}6 \\
5\end{array}$ & 14 & 1.56 & 0.195 & & & & \\
\hline
\end{tabular}

\subsubsection{Hypothesis 1}

Cooperative learning methods have more effects on math progress in comparison to direct method.

H0: Cooperative learning methods have no more effects on math progress in comparison to direct method.

H1: Cooperative learning methods have more effects on math progress in comparison to direct method.

Table 11: Table of Independent $T$ - Test Results for Comparison of Averages of Control and Test Groups for the First Hypothesis

\begin{tabular}{|c|c|c|c|c|c|c|c|c|}
\hline $\begin{array}{l}\text { Index } \\
\text { Group }\end{array}$ & $\mathrm{N}$ & M & $\begin{array}{l}\text { M.S. } \\
\text { E }\end{array}$ & $\begin{array}{l}\text { M.D.S. } \\
\text { E }\end{array}$ & $\begin{array}{l}\text { S.E.D. } \\
\text { M }\end{array}$ & $\begin{array}{l}\text { F. } \\
\text { D }\end{array}$ & $\mathrm{T}$ & S.G \\
\hline Test & $\begin{array}{l}6 \\
5\end{array}$ & $\begin{array}{l}15.7 \\
5\end{array}$ & 1.53 & 0.21 & \multirow{2}{*}{0.212} & \multirow{2}{*}{$\begin{array}{l}12 \\
8\end{array}$} & \multirow{2}{*}{$\begin{array}{l}5.4 \\
2\end{array}$} & \multirow{2}{*}{$\begin{array}{l}0.00 \\
1\end{array}$} \\
\hline $\begin{array}{l}\text { Con- } \\
\text { trol }\end{array}$ & $\begin{array}{l}6 \\
5\end{array}$ & $\begin{array}{l}13.9 \\
9\end{array}$ & 1.65 & 0.205 & & & & \\
\hline
\end{tabular}

Based on the data in table above, results of independent t- test for comparison of control and Test groups averages show that the average scores of Test group in academic progress post - test is (15.75) and SD (1.53) but average scores of control group is (13.99) and SD is (1.65). Now based on calculated t-test which its amount was $(5.24)$ and its significance level was $(\mathrm{p}=0.001)$ and is less than (0.05), thus $\mathrm{H} 0$ is rejected and its opposite is confirmed. Therefore, we can postulate that there is significant difference between averages of two groups in terms of statistics.

\subsubsection{Hypothesis 2}

There is significant difference between math progress of girl and boy students in cooperative learning.

H0: There is no significant difference between math progress of girl and boy students in cooperative learning.

H1: There is significant difference between math progress of girl and boy students in cooperative learning.

Table 12: Table of Independent $T$ - Test Results for Comparison of Averages of Control and Test Groups for the Second Hypothesis

\begin{tabular}{|c|c|c|c|c|c|c|c|c|}
\hline Index & & & & & & & & \\
\hline $\begin{array}{l}\text { Grou } \\
\mathrm{p}\end{array}$ & $\mathrm{N}$ & M & $\begin{array}{l}\text { M.S. } \\
\text { E }\end{array}$ & $\begin{array}{l}\text { M.D.S. } \\
\text { E }\end{array}$ & $\begin{array}{l}\text { S.E.D. } \\
\text { M }\end{array}$ & $\begin{array}{l}\text { F. } \\
\text { D }\end{array}$ & $\mathrm{T}$ & S.G \\
\hline girl & 3 & 15.7 & 1.43 & 0.18 & & & & \\
\hline boy & $\begin{array}{l}5 \\
3 \\
0\end{array}$ & 15.7 & 1.72 & 0.172 & 0.169 & 63 & $\begin{array}{l}2.8 \\
0\end{array}$ & $\begin{array}{l}0.15 \\
6\end{array}$ \\
\hline
\end{tabular}

Based on the data in table above, results of independent t- test for comparison of girl and boy students of control and Test groups averages show that the average scores of girl subject in academic progress post - test is (15.77) and SD (1.43) and average scores of boy subject of the same group is (15.70) and SD is (1.72). Now based on calculated t-test which its amount was (2.80) and its significance level was $(\mathrm{p}=0.156)$ and is more than $(0.05)$, thus $\mathrm{H} 0$ is accepted. Thus, there is no significant difference between math progress of girl and boy students in cooperative learning. 


\section{Conclusions}

The first hypothesis: Cooperative learning methods have more effects on math progress in comparison to direct method.

Based on the results mentioned in deduction findings of section 4, significant difference between averages of two control and exper iment group is shown using parametric $\mathrm{t}-$ test. Thus as an answer to the first hypothesis, we can say that there is significant difference between two groups and subject under cooperative method progressed more than control subject under direct method. Regarding to the fact that in cooperative approach students are responsible for their learning and also other team mates, thus interaction is created and by being in learning and problem solving situation, learn better. On the other hand, the nature of math concepts and subjects has facilitated group work and they make better their learning by teaching to each other and helping weak students. This learning method provides thinking opportunity, creativity, rational thinking and interactive experience all together and has positive effect on their academic achievement; what traditional and direct methods lack.

It should be noted that the conclusion about the first hypothesis is consistent with findings of Cutlin et al (2003), Herried (2000), Gardner and Gioler (2008), Johnson and Johnson (2000), Slavin et al (quoted from Arndes, 1998), Cole and Chan (1990), Karamati (2002), Kenedy (quoted by Ghodrati, 2001), and Sirafi (quoted by Ghodrati, 2001), Khoshbakht (2001), and karamati (2009). This finding is consistent with Meta - analysis about investigating 45 study findings bout impacts of cooperative learning on students' academic progress and thus the first hypothesis is confirmed.

The second hypothesis: There is significant difference between math progress of girl and boy students in cooperative learning.

In response to the second hypothesis related to the difference in math progress in boy and girl students under cooperative learning, it can be said that there is no significant difference between two genders' averages.

Results show that there is no significant difference between math progress of girl and boy students. It should be noted that concluding about the second hypothesis is not consistent with findings of Herried (2000), Vitoria et al. (quoted by karamati, 2003) but is consistent with peterson's results (quote by neysi, najarian and sheykhani, 2004) and karamati (2009).

Based on the results we can conclude that using cooperative approach and its wide range styles can improve students' academic progress and help them in achieving academic goals, thinking about material in books and promoting their skills.

This approach can reduce teacher's speeches and give the leading role in teaching process thus learning is increased and interaction between students and teachers is provided so one - way classes become full of energy and cooperation between teacher and students. In addition, this approach provides learning experience for learning method for students and provides situation to reduce the amount of problems resulted from traditional learning and entering into world of modern technology.

\section{Suggestions}

1) It is better that cooperative method be used instead of traditional methods in order to promote academic progress of students.

2) Other universities make familiar their teaching staff by holding workshops.

3) Use this method for teaching courses that their learning needs interactive cooperation of teacher and student.

4) We suggest this study to be conducted in other universities.

5) Other studies investigate the effect of the method on other courses.

6) It is suggested that the effects of cooperative approach on students' behavior out of the class, in particular work environment be studied
7) Due to the fact that semi experimental framework is used in this study, thus using complete experimental method would reveal many facts about cooperative method and other types of learning and teaching.

\section{References}

[1] Alamol, hodaie, S. H. (2009). Principles of Math Training. Mashhad: Donyaye Farda Publishing.

[2] Arends, R. (1998). learning to teach. boston: Mc Grow hill.

[3] Bahmayi, L. (2011). New Ideas for Wondering (Primary). Tehran: Aradaktab.

[4] Brown, w \& Brown, B. (1998). Cooperative learning in latin America. international jornal of education research, vol 29.no 2

[5] Col, P \& ChanL. (1990). Methods and Strategies for special Education. prentice-hall

[6] Cohen, E. (1994). Desiging groupwork teacher. College press, Columbiana university.

[7] Delavar, A. (2013). Uses and Practices in Psychology and Educational Sciences. Tehran: Roshd Publication.

[8] Elliot, S. N \& et all. (1996). Educational psychology. Usa:brown and benchmark

[9] Gardner,J,N. \& Jewler ,J,A.(2008).Your College Experince. USA:Wodsworth Publishing Company.

[10] Ghodrati, M. (2001). Comparison of the Effect of Participatory Learning with Individual Learning on the Level of Understanding, Understanding, Understanding, Analyzing and Deciding Science in the Empirical Science Session of the 5th Grade Students. Graduate Diploma: Allameh Tabatabaei University.

[11] Herried, C, F. (2000). Why isn't cooperative learning used teach scince? American institute of science.

[12] Jacobes, G. \& et All. (2002). The Teachers Sourcebook for cooperative learning. Gorwin inc.

[13] Johnson, D. W. \& Johnson R. T. (1989). Cooperation and com petrtion:theory and research.edina,M.N:iteraction book company

[14] Johnson R. T \& Johnson, D. W. (1982). effect's of cooperative competitive and individualistic learning on student in scinse class jornal of research in scince teaching, 19.

[15] Karamati, M. R. (2009). Comparison of Participatory Learning Methods, Participatory Learning with Learning the Principles of Dialogue, and Lecture on the Academic Achievement of Geography of Primary V Students. Educational and Vocational Education, No. 100.

[16] Karamati, M. R. (2002). A Study on the Impact of Collaborative Learning on the Advancement of Social Skills and Mentoring Academic Achievement in the Fifth Grade Students of Shahid Moshhad in the academic year of 81-82. PhD Thesis. Tehran: Tarbiat Moallem University.

[17] Kathleen. j. k \& et all. (2003). A comparision of cooperative learning and small group indiviualized instruction for math in a selfcontained classroom for elementary students with disablties.educational research quarterly, stanford university. Vol 24.3.

[18] Khoshbakht, F. (2001). The Impact of Participatory and Individual Education on Free Learning and Reminder. Graduate Certificate. Shiraz University.

[19] Saif, A.A. (2003). Effect of teaching learning strategies on the speed of reading, recalling and comprehension of different texts. Educational and teaching dissertation. The nineteenth century. The number two

[20] Saif, A.A. (2013). Modern educational physiology. Tehran: Agah.

[21] Sha'bani, H. (2011). Educational skills. Tehran: Samt.

[22] Slavin, R, E. (2012). Educational psychology. New York: Pearson.

[23] Talebi, M. (2005). Comparison of the Effect of Participatory and Technological Learning Methods on Academic Achievement and Attitude to Learning in Mathematics Course of Secondary School Students in Urmia Schools in 2005. Graduate Diploma: Tabriz University. 